\title{
8. THE LANDSCAPE - A SYSTEM OF PLASTIC EXPRESSIONS
}

\author{
Iarîna Savițkaia-Baraghin ${ }^{233}$
}

\begin{abstract}
The principles of mastering landscape painting, applied by past masters, as well as theoretical elaborations in the field of chromatics, psychology and pedagogy of the arts, become important components in the improvement of outdoor painting in contemporary conditions.
\end{abstract}

Key word: landscape, plain-air, study, painting, composition

\section{Introduction}

The monuments of culture and art of the ancient world, preserved to this day, testify that people, since ancient times, have tried to reproduce in images the nature around them. Elements of the landscape can be found in cave drawings. Primitive man probably felt inextricably linked to the world around him, so he was not at all interested in the idea of a pure landscape. However, according to the history of the arts, overcoming a certain selfishness towards the landscapeenvironment, in the human consciousness, was achieved gradually and quite slowly. Thus, for example, in the murals of the ancient Egyptians, nature is not presented, but the landscape is recorded by equivalent elements: lotus, rush, trees. $[1 ; 2]$.

\section{Discussions}

Even the ancient Greeks did not know the landscape as a special genre. They drew a strip of earth or a bank with pebbles just to mark the place of action. During the Roman Republic there were images similar to our perception of the landscape. The painters who created them had a certain imagination about the linear and aerial perspective, although not so consistent. As an independent genre, landscape appears in Chinese art in the sixth century. Paintings from medieval China poetically portray the world around them. During the Min dynasty, however, the landscape lost its importance in painting.

In Europe, the landscape, as a separate genre of art, appeared much later than in China or Japan, being, initially, a component part of the mythological scenes in painting in Antiquity and the Middle Ages. In antiquity and the Middle Ages, landscapes served as a background for frescoes, reliefs and icons, determining the semantics of scenes, generally limited. During this period, the landscapes lack illusory volumes, they are clumsy as a drawing, with a symbolized character. As I. Frunzetti, art critic, stated: The landscape has at the beginning the function of decoration of the compositional painting. ${ }^{234}$ It is necessary to mention the unique phenomenon in the area of European art - the medieval Moldavian frescoes from

\footnotetext{
${ }^{233}$ Associate Professor PhD., Academy of Music, Theatre, Fine Arts from Chişinău, Republic of Moldavia, email: siarina2002@yahoo.com

${ }^{234}$ Frunzetti, Ion. Etapele evoluției peisajului în pictura Românească până la Grigorescu În: Studiu și cercetări de istoria artei, anul VIII, 1, București: Academia Republicii Populare Romîne, 1961, p.85
} 
northern Moldova, known through the decoration of the churches from the XVXVI centuries: Pătrăuţi monasteries (1487), Voroneţ (1488) [3], Arbore (1503) [4 ], Sucevita (1522) [5], Humor (1530) [6], Probota (1530) [7] and Moldovita (1532) [8].

In the Republic of Moldova, the only monument in which the mural painting executed in the fresco technique is preserved is in the city of Causeni, in the Church of the Nativity of the Mother of God (16th-17th century, Figure 3) [9]. As an artistic value, the landscape has expanded throughout the arts, becoming a generalizing factor of contemporary fine arts in Moldova. The genre of landscape in Moldova appears in various aspects, depending on the interest and preference of the artist, easel or book graphics, which he treats according to temperament, through complex rationalism, through geometric or lyrical abstractionism, through surrealism, symbolism, through conventional-decorative forms, with a theatricalization of the action, but each stage, in the artistic life, is imposed not only by its achievements, but also by the integral re-evaluation of the works that once constituted the patrimony [10, pp. 54-59 ].

Landscape is the most popular genre of fine art, being approached, practically, by every painter. A wide range of possibilities for working with images in nature allows each artist to develop their own style. The natural environment of the visible world, in all its integrity and harmony, is an inexhaustible source of knowledge, analysis and perceptions, a precious source of ideas and principles that a professional artist uses for the social and cultural transformation of space. C. Korovin wrote about the landscape as follows: The landscape cannot be painted without any purpose, just because it is beautiful, it must contain the history of the soul. It must be like the sound that corresponds to cordial feelings. It is difficult to express this in words, it is so much like music ${ }^{235}$.

The landscape is a view of nature, and as a genre of fine arts it is identified, by creating an image of nature or a locality, with various aspects of the expressive picturesqueness and the charm of concrete or imaginary places [11, p. 28]. Giorgio Vasari uses the term landscape with the meaning of "view as a subject of painting". Danielle Bartoli considered that the landscape seen [...] through the hollow of a window or through any opening, to her liking, is shown in the distance as a landscape in blurred tones ${ }^{236}$. Pierto Fantani and Jiuseppe Rigutini define the landscape as a whole view or a part of it, insofar as it is chosen to be the subject of painting [12, p. 241]. According to Assunto, the landscape is an element in a complex system, which includes space, place and time alike ${ }^{237}$.

Nicola Zingarelli, the most famous Italian philologist of the interwar period, in Vocabolariu de la lingua italiana, treats the term landscape as an aspect of the view, a stretch of inhabited and civilized land, held with plains, mountains, rivers, trees, etc. or as a wonderful (...) landscape of the earth's panorama ${ }^{238}$. The

\footnotetext{
235 Коровин К., Жизнь и творчество, письма, документы, воспоминания. Москва: Академия художеств CCCP, 1963. p. 55

${ }^{236}$ Bartolli D., Omul desăvârşit. Torino, 1836. p. 89

${ }^{237}$ Assunto R., Peisajul şi estetica (tradus în română de Olga Mircelescu). Bucureşti: Meridiane, vol. I, 1986. p. 158

${ }^{238}$ Zingarelli N., Dicţionarul limbii italiene. Florenţa: Zanichelli, 1941. p. 48
} 
landscape is a space in which things are placed, the objects seen as a whole, and its embodiment in art is the representation of space, which reflects or includes a complex vision of the micro- or macrocosm. By interpreting the space where the beginning and the infinite merge, the landscape can be interpreted as an outer space - of a locality or a view, seen panoramic, or as an interior space -, perceived on a smaller dimensional scale, representing only a fragment of the vastness of the landscape. [13]. The process of making the landscape in art denotes that it is a cultural and intellectual product, dateable and explicable from the point of view of history.

\section{Results}

Practice shows that students who are accustomed to working in workshop conditions, going out in the open air, get lost in the search for color relationships in the air. Consequently, the color palette becomes quite limited, a fact sharply mentioned by the well-known eighteenth-century French Enlightenment Denis Diderot: He who did not study and did not feel the effect of light and shadow in fields and forests on the roofs of village houses and urban, day and night, to leave the brush in his hand, in particular, not to think of becoming a landscape painter [14, p 57]. In the landscape there is a traditional rule: the sky and the landscape, according to their compositional mass, must not be equal. If the painter aims to show huge, boundless expanses, he reserves most of the painting to the sky and pays the main attention to it as well. If the task consists in the meticulous rendering of the landscape, then the boundary between the sky and the landscape, as a rule, is located much higher than the optical center of the composition. If the border is placed in the middle, the image will be divided into two parts, which will claim equal priority, and thus the principle of subordination of the secondary to the main will be violated $[15$, p. 20].

When proceeding to the landscape study, it is necessary, first of all, to take care of choosing the best observation point, from where the whole landscape will be perceived in its entirety, in all its expressiveness and all the spatial plans will be determined exactly. If in the composition of the study we intend to reproduce the trees in their entirety, then it is necessary to be at a certain distance from them (at not less than 2-3 sizes of the object reproduced in its largest part). One of the main compositional tasks is to fix from the very beginning on the surface of the paper the major ratio between heaven and earth.

All elements of the landscape will be further constructed according to the position of the horizon line (located at the level of our eyes). The horizon must not divide the plane of the painting with a horizontal line in two parts. The study will look more interesting if there will be more heaven or more earth on it, but not proportional equity. Symmetry makes the compositions expressionless and boring. In nature, where the colors of objects change depending on the lighting, we have to decide where to build the color ratios. If, in the absence of experience, we do not pay attention to these parameters, we will have to permanently rewrite the study started; for example, when the sunny weather will be gloomy. 


\section{Conclusions}

The experience gained in the work process, the works made in different graphic techniques, simultaneously with the study of various materials and means of expression, will be the baggage that graduates will use throughout their creative path. It is necessary for the painter to possess a developed sense of imaginative plastic perception of nature, the ability to penetrate deeply into its chromatic state. Creating the landscape is impossible without applying the laws of linear and aerial perspective. Familiarizing students with the genre of fine arts - the landscape, not only through perception, but also through practical activity, enriches them spiritually. For this, it is necessary to create conditions - students must be taught to work with various artistic materials, to understand the language of fine arts, to use the means of plastic expression. At the same time, it is necessary to permanently enrich the visual imaginations of the students and to update the accumulated experience. We find, thus, that the landscape, being a system of artistic expressions, a special language, whose elements correspond to conventional signs, carries its content as a unique and mystical message.

\section{References}

1. Plinius cel Bătrân. Naturalis Historia: Enciclopedia cunoştinţelor din Antichitate (traducere de Costa Ioana), 2000, Polirom, Iaşi, 312 p

2. Kultermann U., Istoria istoriei artei, Vol. 1, Meridiane, Bucureşti, 1977, 278 p

3. Comarnescu P., Voroneț, Meridiane, București, 1967, $59 \mathrm{p}$

4. Caproşu I., Biserica Tăierea Capului Sf. Ioan Botezătorul din Arbore, Editura Mitropoliei Moldovei și Sucevei, Iași, 1974, 137 p

5. Nicolescu C., Suceviţa, Editura Sport-turism, Bucureşti, 1977, $24 \mathrm{p}$

6. Drăguţ V., Humor, Meridiane, Bucureşti, 1973, 40 p

7. Ciobanu C., O redacţie iconografică rară descoperită în pictura murală a altarului Bisericii Sfântului Nicolae a Mănăstirii Probota, În: Arta, 2003, p. 19-22, Editura Grafema-Libris, Chișinău

8. Nicolescu C., Mănăstirea Moldoviţa, Meridiane, Bucureşti, 1965. 37 p

9. Ciobanu C., Biserica Adormirii Maicii Domnului din Căuşăni. Editura Ştiinţa, Chişinău, 1997, 163 p

10. Stavilă T., Ciobanu C. I., Diaconescu T. Patrimoniul cultural al Republicii Moldova. Editura Arc/ Museum, Chişinău, 1999, pp. 54-59

11. Munteanu A., Peisajul artei vizuale în contextul evoluţiei. În: Arta, Arte Vizuale, Editura Notograf, Chişinău, 2010, p. 28

12. Assunto R., Peisajul şi estetica (tradus în română de Olga Mircelescu), vol. I, Meridiane, Bucureşti, 1986, p. 241

13. Munteanu A., Specificul peisajului în arta Moldovei medievale. În: Culegere de articole din cadrul Conferinţei Tehnico-Ştiinţifice Internaţionale „Problemele actuale ale urbanismului şi amenajării teritoriului”, din 11-12 noiembrie 2010, U.T.M., Chişinău, volumul I, p. 112-117

14. Беда Г., Основы изобразительной грамоты: Рисунок. Живопись. Композиция. Просвещение, Москва, 1981, р. 57

15. Непомнящий В., Перспектива в композиции. Чувашский государственный педагогический университет, Чебоксары, 1970. p.20 